\title{
Combined geoelectrical and geoelectromagnetic survey for contributing to local hydrogeological regime - The case study of Delfini basin (Chios isl. - Greece)
}

\author{
T. D. Papadopoulos $\mathbb{D}$, J. D. Alexopoulos $\mathbb{D}$, S. Dilalos $\mathbb{D}$ \\ Division of Geophysics and Geothermy, Department of Geology \& Geoenvironment, \\ National and Kapodistrian University of Athens, Panepistimiopolis 15784 Zografos, \\ Athens, Greece, e-mail: tpapadop@geol.uoa.gr
}

Received: 05.03.2020, revised: 25.03.2020, accepted: 27.03.2020

\begin{abstract}
Relevance. In this paper the feeding mechanism of springs distributed around the broader area of Delfini at NE side of Chios Island is explored, in an effort to locate possible fresh water paths inland before they are discharged to the sea. The drilling of hydro wells for more production is of vital importance to cover the drinking and irrigation needs of the broader area. Aim. Although Chios has been extensively drilled in the past years the demand for further investigations comes from an increased water consumption during summer time in one hand and the inefficiency of alternative water resources (e.g. construction of dams, desalination units, etc) on the other hand. Methods. Geophysical methods were used (VLF and resistivity) to explore in detail water potential areas, like the broader area of Delfini, where during winter time huge quantities of fresh water discharge through springs to sea level. Results and its discussion. The presence of a confined aquifer composed mainly of limestones, which are overlain by clastic impermeable deposits, together with the existence of water potential bearing fracture zones determine the hydrogeological regime of the nearby area. It is also explained the presence of brackish waters at positive elevations found during summer time at nearby springs. It seems that the lateral extent of impermeable clastic deposits plays a crucial role in allowing the inland flow of seawater during summer time and combined with the presence of the confined aquifer of fresh water produce an upward mixing flow of fresh and seawater at springs of positive elevations. During winter time the huge amount of fresh water discharges do not allow the inland flow of seawater.
\end{abstract}

Keywords: Resistivity, VLF, Spring Mechanism, Seawater Intrusion, Geoelectrical basement.

Acknowledgments: The authors would like to thank Mr. Pippidis Michael, for his valuable hydrogeological conversations and guidelines, Mr. Mourounas loannis, director of Water Management Organization and Tomara V., Goumas G., Drossopoulou E., Staurou A. \& Nikolis V. for their contribution during the fieldwork campaigns.

For citation: Papadopoulos T. D., Alexopoulos J. D., Dilalos S. Combined geoelectrical and geoelectromagnetic survey for contributing to local hydrogeological regime - The case study of Delfini basin (Chios isl. Greece). Geologiya I Geofizika Yuga Rossii = Geology and Geophysics of Russian South. 2020.10 (1): 68-80. DOI: 10.23671/NNC.2020.1.59066. 
Оригинальная статья

Комбинированные геоэлектрические и геоэлектромагнитные исслеАования вк^аАа

в местный гиАрогеологический режим на примере бассейна $А$ бьфини (остров Хиос - Греция)

\author{
Т. Д. Пападопулос ${ }^{(D)}$, Дж. Д. Алексополус (D), С. Дилалос (D) \\ Национальный Афинский университет им. Каподистрии, факультет геологии \\ и геоэкологии, отдел геофизики и геотермии, Панепистимиополис, \\ г. Асрины 15784, Греция, e-mail: tpapadop@geol.uoa.gr \\ Статья поступила: 05.03.2020, после рецензирования: 25.03.2020, принята к публикации: 27.03.2020
}

Резюме: Актуальность. В данной статье исследуется механизм питания источников, распределенных вокруг широкой области Дельфини на северо-восточной стороне острова Хиос, в попытке найти возможные пути фильтрации пресных вод внутри острова, до того как они будут сброшены в море. Цель. Бурение гидрогеологических скважин для увеличения добычи имеет жизненно важное значение для удовлетворения потребностей в питьевой воде и ирригации широкой территории. Несмотря на то, что в последние годы на острове Хиос интенсивно бурятся скважины, потребность в дальнейших исследованиях связана с увеличением потребления воды в летнее время, с одной стороны, и неэффективностью альтернативных водных ресурсов (например, строительство плотин, опреснительных установок и т.д.), с другой стороны. Методы. Геофизические методы (низкочастотная электроразведка и удельное сопротивление) использовались для детального изучения областей водного потенциала, таких как наиболее широкая область Дельфини, где в зимнее время огромное количество пресной воды сбрасывается через источники до уровня моря. Результаты и их обсуждение. Наличие ограниченного водоносного горизонта, состоящего в основном из известняков, которые перекрыты обломочными непроницаемыми отложениями, а также наличие разрывных зон, несущих водный потенциал, определяют гидрогеологический режим близлежащего района. Это также объясняется наличием солоноватых вод на положительных высотах, обнаруженных в летнее время в близлежащих источниках. По-видимому, боковая протяженность непроницаемых обломочных отложений играет решающую роль, позволяя внутреннему стоку морской воды в летнее время и в сочетании с наличием ограниченного водоносного горизонта пресной воды создавать восходящий смешивающийся поток пресной и морской воды в источниках возвышенностей. В зимнее время огромное количество оттока пресной воды не позволяет внутреннему притоку морской воды.

Ключевые слова: удельное сопротивление, низкочастотная электроразведка, пружинный механизм, вторжение морской воды, геоэлектрический фундамент.

Благодарности: Авторы хотели бы поблагодарить г-на Пиппидиса Майкла за его ценные гидрогеологические беседы и руководства, г-на Мурунаса Иоанниса, директора Организации по управлению водными ресурсами и Томару В., Гумас Г., Дроссопулу Э., Стару А. и Николис В. за их вклад во время полевых исследований.

Для цитирования: Пападопулос Т.Д., Алексопулос Дж. Д., Дилалос С. Комбинированные геоэлектрические и геоэлектромагнитные исследования вклада в местный гидрогеологический режим - на примере бассейна Дельфини (остров Хиос - Греция). Геология и геофизика Юга России. 2020.10 (1): 68-80. DOI: 10.23671/NNC.2020.1.59066. 


\section{Introduction}

The island of Chios has been extensively drilled for water exploitation the last two decades, in an effort to cover the needs of water supply in urban and rural areas. The demand for greater quantities of water consumptions increases particularly during summer. The hydrogeological basin of «Korakari» is considered as the most water productive area in Chios Isl., providing $>80 \%$ of the water supply and $>70 \%$ covering of the irrigation needs of the island [Banos et al., 1995]. Although it seems that the water supply problem is not intense, however some production wells appear an abnormal increase in mercury $(\mathrm{Hg})$ content, around the area of «Korakari» during summer. This problem requires the investigation of other potentially productive areas. Of course, local authorities and governmental agencies have also proposed other more permanent solutions like the construction of dams (e.g. Katraris, Fyrolakas, Koris Gefyri, Sarapio, etc.) and the establishment of desalination units. The construction of dams started long time ago but still are out of operation, mainly because of financial problems. Desalination units were also put forward in the area of Lagada in NE Chios but their maintenance cost is high so they were not used in other places. Besides these intermediate and long-term solutions, other approaches were proposed to cover immediate needs and solve the water supply problem in Chios Island.

A geophysical survey was proposed to search for new potentially promising areas for further drilling [Dilalos, 2009]. These areas must fulfill the following prerequisites: a) To be in regions that are not extensively drilled by previous works, b) to be in accessible places in order to be reached easily by a drilling machine, c) to be in areas that are promising from a hydrogeological point of view based on the detailed consideration of the geological structure and the potentiality of the geophysical methods used and d) to be close to the existing water pipe network for direct connection of the new productive wells. As it is obvious, the constraints mentioned above, make the problem more complicated and impose specific geophysical methods to be used. These methods have been successfully applied in the past in similar geoenvironments [Alexopoulos et al., 2007; 2008; 2011; 2013; Banks et al., 1994; Bernard et al., 1991; Benson et al., 1977; Monteiro Santos, 2006; Papadopoulos, Alexopoulos, 1999; Paraskevopoulos, Papadopoulos, 2002; Sharma, Baranwal, 2005; Sree Devi et al., 2001; Stournaras et al., 1993] and in other cases for the investigation of seawater intrusion [Alexopoulos et al., 2019; Albouy et al., 2001; Yang et al., 1999], which is also under investigation here.

In order to detect vertical or sub-vertical conductive zones the VLF method was applied. From the areas that were explored the region of Delfini was extensively surveyed. Great surface water discharges appear close to sea level (SP1 at $+4.2 \mathrm{~m}$ elevation, SP2 +2.6 to +0.9 and SP3 \pm 0 ; fig. 1) in the broader area of Delfini. The idea was to study possible water paths through karstic structures or fault zones before the water discharges to sea level. The detailed geological mapping of the area under investigation helped us to draw the appropriate geophysical profiles. Besides VLF measurements, resistivity soundings were also conducted to investigate seawater intrusion and the depth of carbonate rocks under the alluvial deposits in Delfini plain.

\section{Geological setting}

Chios Island can be subdivided into two tectonostratigrarhic units [Besenecker et al., 1968]:

First, an autochthonous unit (Fig. 1) which consists from the base of mainly clastic rocks of late Palaeozoic age, that are overlain by a succession of early Triassic conglom- 


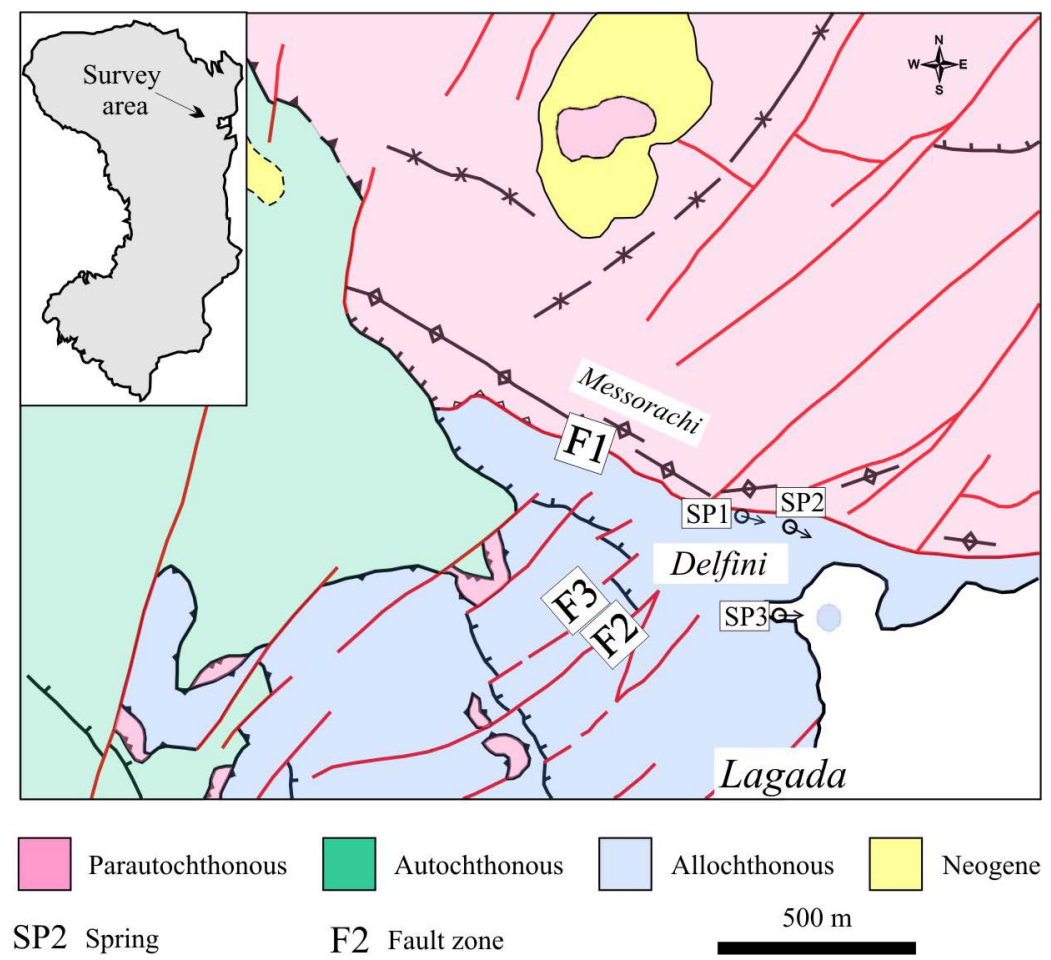

Fig. 1. Major tectonostratigraphic units of the survey area [Kauffmann, 1969]. I

Рис. 1. Основные тектоно-стратиграфические единиџы района съемки [Каиffтапn, 1969].

erates, sandstones followed from well bedded limestones of late early Triassic age and massive limestones interbedded with reddish Hallstatt type limestones. This sequence is overlain by an Anisian volcano-sedimentary succession, followed by the well-bedded marly limestones of late Anisian and a more than 1000 meters thick Ladinian to Rhaetian - Liassic age limestones, with few clastic intercalations (emersion horizons).

Second, an allochthonous unit (Fig.1) which overlies parts of the autochthonous/parautochtonous basement and consists of a lower horizon of quartzose graywakes, sandstones and minor siltstones of late Carboniferous age, followed by limestones and a clastic carbonaceous succession of early Permian age. The middle Permian is represented by carbonate sequences, which are overlain by transgressive sediments (conglomerates, sandstones, siltstones followed by thick bedded Dachstein-type limestones and minor dolomites) of early Jurassic age. Tectonically between these two units are caught parts of the autochthonous succession as parautochthonous unit. The formations of the Aepos - Pytious karstified plateau, which comprise the hydrogeological basin of the study area, belong to the autochthonous unit, with the exception of the Delfini depression where the allochthonous unit lies over the autochthonous and in places the parautochthonous basement. The parautochthonous formations are well developed further north on the Kardamyla - Skoukla peninsula. The detailed geological setting of the study area is shown in figure 2.

The Chios Isl. is located in the middle of an area dominated by crustal extension since Miocene period, with generally NNE to SSW direction, which results in E to W trending normal faults. The extensional regime is conjugated with NE to SW and NW to SE strikeslip deformations and $\mathrm{E}$ to $\mathrm{W}$ compression. The Anavatos - Koila fault divides the ground water basin into two almost equal east and west parts and outlines the western boundary of the Delfini depression (Fig. 3). Subparallel to it and eastward lies the Tria Pigadia - 


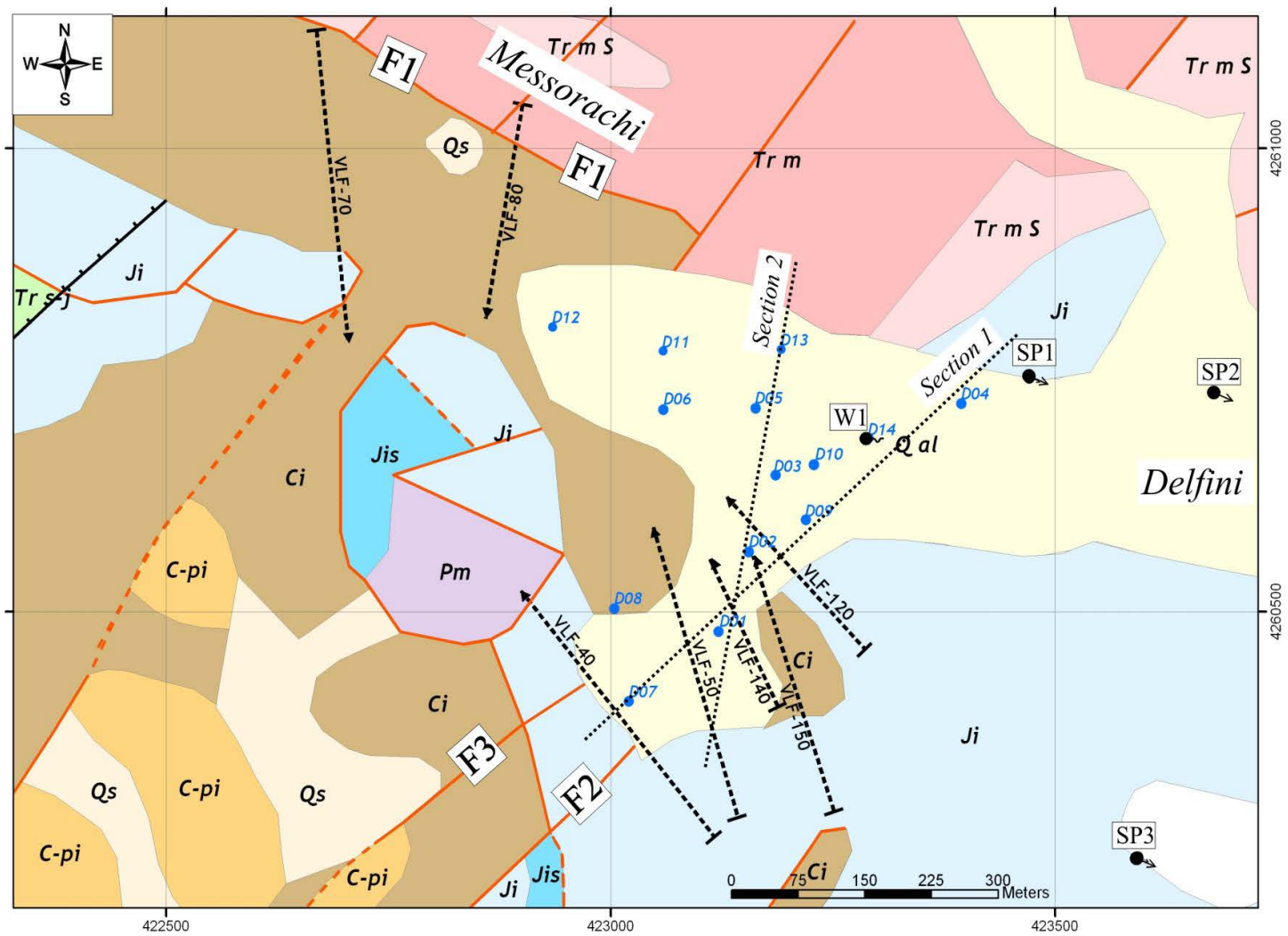

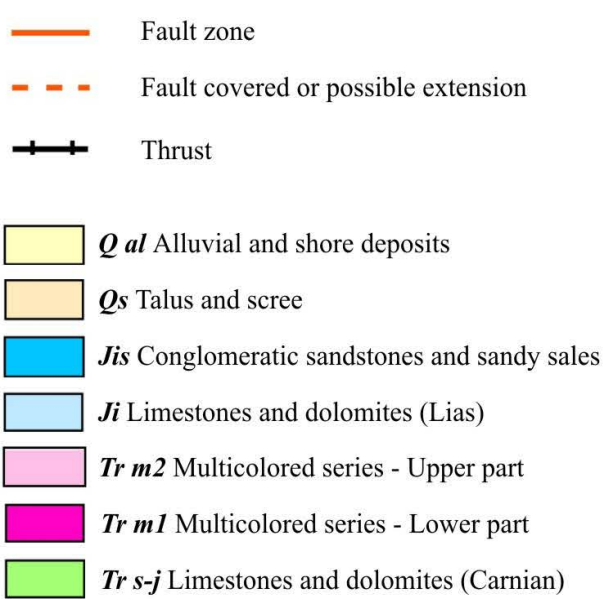

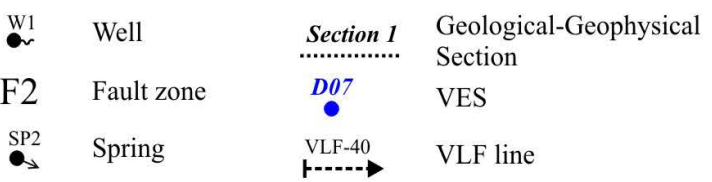

Fig. 2. Detailed geological map of the survey area along with the VLF traverses and geoelectrical soundings (Chios Sheet, Kauffmann G., Institute for Geology \& Subsurface Research, 1971). I

Puc. 2. Подробная геологическая карта района исследования, а также траверсы низкочастотной электроразведки и геоэлектрическое зондирование (лист Хиос, Кауфман Г., Институт геологии и подземных исследований, 1971).

Pantoukios fault, which is continued below sea level in the Pantoukios gulf. In NE to SW direction lies the Krikelis fault, which intersects the Anavatos-Koila fault and continues, through the Delfini depression, further north. Parallel to it, shorter faults intersect the allochthonous formations of the Delfini depression and the Skoukla peninsula. In NW to SE, direction lies the Anavatos - Nea Moni fault zone. 


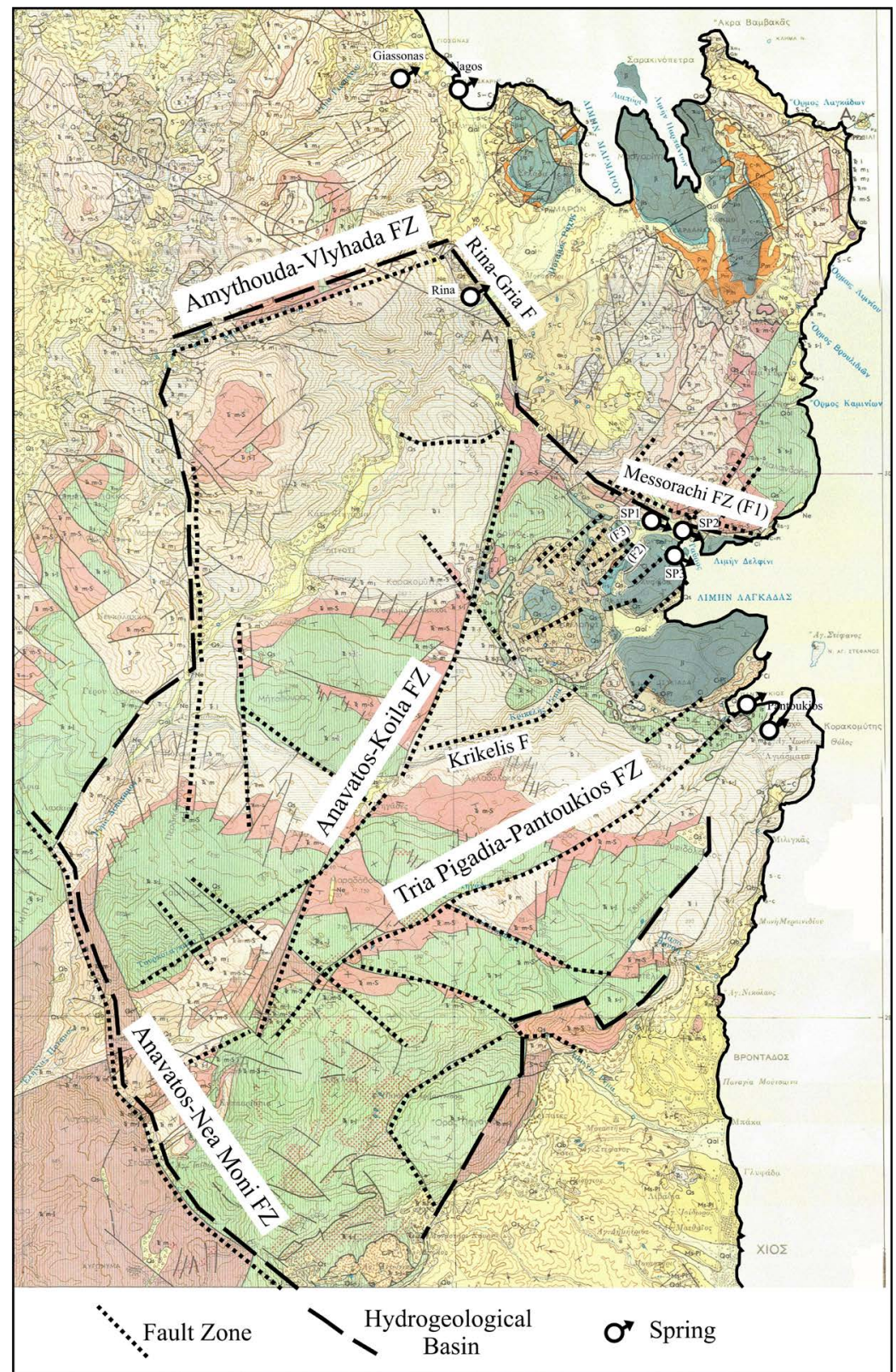

Fig. 3. The broader ground water basin of the area under study along with the main fault zones (modified from geological map «Chios», Institute for Geology \& Subsurface Research, 1971). I Pис. 3. Широкий бассейн подземных вод исследуемой территории вместе с основными зонами разломов (модифицировано по геологической карте «Хиос», Институт геологии и глубинных исследований, 1971 г.).

\subsection{Hydrology and watershed of the Delfini karstic coastal system.}

The central part up to NE of Chios Isl. is covered by a large limestone plateau of Jurassic- Triassic age, with a complicated tectonic structure. The limestone plateau, stays from about $>800 \mathrm{~m}$ WSW to $400 \mathrm{~m}$ ENE above sea level and its north eastern termination (the Delfini-Kardamyla depression) from $>200 \mathrm{~m}$ to below sea level (the depth of the sea bottom, which forms an underwater plain in front of the depression is constantly 70 to 80 $m$ ). The major part of the plateau is intensely karstified and the annual rainfalls exceed $700 \mathrm{~mm} / \mathrm{y}$ (>90\% of the total rain) during the winter months, from October to April. The majority of the plateau surface is a denudated karst covered of scarce scrub of low vegeta- 
tion which presents high infiltration rates that are estimated more than $30 \%$ and locally $>45 \%$. Between the gulfs of Pantoukios and Delfini, the watershed dips below sea level, to a depth of about $70-80 \mathrm{~m}$. The East - North borders are designated from the contact between the parautochthonous and the allochthonous unit in the Messorachi region, the Delfini tectonic zone and the north part of the Anavatos-Koila fault zone (Fig. 3). In the north, the fault zone Amythounda-Vlyhada separates the Delfini hydrogeological unit from the Nagos-Giosonas unit. The watershed basin of the Delfini karstic coastal system, covers more than $90 \mathrm{~km}^{2}$ and the yearly discharge may exceed $30 \times 10^{6} \mathrm{~m}^{3}$, a quantity that is almost three times higher than the actual water demand/consumption on the island. The possible borders of the broader ground water basin that feeds with huge water discharges the gulfs of Pantoukios and Delfini are shown in figure 3.

\subsection{Hydrogeological aspects of the Delfini aquifer}

The Palaeozoic clastic rocks of the autochthonous unit form the impermeable basement. The early Triassic conglomerates, sandstones, the well bedded limestones which follow, the massive limestones which incorporate Hallstatt inclusions and the more than 1000m thick Ladinian to Rhaetian - Liassic limestones, form the potential permeable cover. The Anisian volcano-sedimentary succession and the well-bedded marly limestones, together with the emersion horizons can form impermeable layers. The quartzose graywakes, sandstones and siltstones of the lower horizon form a possible discontinuous impermeable layer, together with the clastic carbonaceous succession of the early Permian and the clastic sediments in the base of the thick-bedded limestones and dolomites, which close the stratigraphic sequence of the allochthonous unit. The Dachstein type thick-bedded limestones, of early Jurassic age, form a potentially permeable formation. The numerous intersecting faults favored the development of limestone karstification and produced an efficient subsurface drainage system in which probably the Anavatos-Koila fault zone serves as a main collector, which feeds the Krikelis and the parallel to it faults in the Delfini depression.

\subsection{Discharge characteristics of the Delfini karstic coastal system}

The lower part (also below sea level) of the aquifer in the Delfini depression area, which is mainly developed in the autochthonous limestones, is partly (in unknown extent) covered by the impermeable strata of the allochthonous and the parautochthonous formations. This cover protects partly the aquifer which discharges a considerable amount of fresh water at the Giuvari spring (SP3), without mixing with seawater. This spring flows at the intersection of a parallel to Krikelis fault with a thick Quaternary clay cover in the bottom of the small gulf in front of it, at zero elevation. The year round discharge is estimated of more than $0.45 \times 10^{6} \mathrm{~m}^{3}$. The Pantoukios gulf, which forms the extension of the Tria Pigadia-Pantoukios fault, discharges below sea level $(>30 \mathrm{~m})$ big quantities of karst water which are observable at sea surface most of the year. In the Lagada gulf, does not appear any spring over or below sea level. In the north end of the Delfini depression along the Messorachi fault zone area, the Delfini springs (SP1 at $+4.2 \mathrm{~m}$ elevation and SP2 at different locations from $+2,6$ to $+0,9 \mathrm{~m}$ above sea level), discharge more than $5 \times 10^{6} \mathrm{~m}^{3} /$ annually. The fluctuation of the volume and the salinity of the springs depend on the annual rate of the rainfalls, the location of the springs and the elevation of the discharge. Submarine springs along that fault line are not known. On the north end of the watershed, the Rina springs at an elevation of $+56 \mathrm{~m}$ discharge (only during the months of the winter 
a quantity that can vary considerably from 0 to more than $1 \times 10^{6} \mathrm{~m}^{3} / \mathrm{y}$ ) at the intersection of a parallel to Anavatos-Koila fault zone with the Rina-Gria fault which is parallel to Messorachi fault zone.

\subsection{Investigation of the Delfini discharge zone}

Two main springs discharge in the area of Delfini (SP1 and SP2) near the sea level (Figures $2 \& 3$ ). Both springs discharge great quantities of fresh water especially during winter and spring times with very good quality of water. The municipality of Chios through the Water Management Organization (DEYAX) has built aqueducts at spring sites SP1 and SP3 (Giuvari) and supplies the water network of the island. During summer time, the great quantities of discharge run short and the water quality is downgraded as it is affected by the seawater intrusion. The feeding of both springs was an unresolved problem and needed further investigation. In one hand, it seems that the fault zone F1 (figs. 1 \& 2) is responsible for the discharge at site SP1 and on the other hand the parautochthonous series on the NE side of the fault zone does not show water feeding potential since the upper carbonate rocks of the unit are of small extent. Another interesting point is that the spring at site SP1 during summer time (low discharges) presents higher salinity values although lies at positive altitudes $(\sim 4.2 \mathrm{~m})$. The allochthonous series on the SW side of fault zone F1, is generally considered as a non potentially water exploitation region since it is composed from impermeable rocks.

It seems that the springs SP1, SP2 and SP3 (figs $2 \& 3$ ), share a common feeding line, of Krikelis fault and the subparallel to it of smaller faults (e.g. F2 and F3) which are well developed in the Delfini depression and are in some way connected to Anavatos - Koila fault zone. The Messorachi fault zone (F1), intersects almost perpendicularly those faults and probably brings the seawater inland. The faults must affect the main aquifer on the autochthonous basement, which is effectively protected from sea water intrusion, mainly by the cover of the allochthonous unit and probably by the recent clay rich deposits, like the case of spring SP3 (Giuvari). This model of the discharge mechanism must be validated prior to establishment of a viable exploitation scheme of that aquifer in the region around the Delfini valleys and at an elevation of less than $100 \mathrm{~m}$. So, it is necessary to answer the follow questions: Are the NE to SW faults in the Delfini depression affecting the autochthonous basement? Which of the mapped faults are active hydrologically and in which way they are affected by the seawater intrusion? How deep are the impermeable covers? Is the aquifer limited in the fault zone or not? Is the Messorachi fault zone the canal for seawater intrusion? At what depth the drilling must end up, before getting in contact with a deeper mixed with seawater aquifer?

\section{VLF measurements}

VLF measurements were conducted in order to detect vertical to sub-vertical conductive zones or karstic structures in carbonate rocks perpendicular to fault zones as it is shown in figure 2. The spacing between stations was 5 meters and the VLF lines were kept long enough (a length greater than 200m) to outline the VLF anomalies. Although the relief was not smooth along almost all lines, however the filtered data [Walen, 2003; Ogilvy, Lee, 1991, Karous, Hjelt, 1983] provided reliable results without applying topographic corrections.

In the area of Delfini, at least five (5) VLF lines were conducted mainly, to detect the NE extension of fault zones F2 and F3. Two (2) VLF lines were also carried out trans- 
versely to the fault zone F1 to examine its potential relative to SE-ward discharge of Messorachi Mtn. In figure 4 the interpreted filtered data for the Delfini area are shown. The fault F2 is extended NE-ward (fig. 4) up to the plain of Delfini. Fault F3 does not show a clear NE extension.
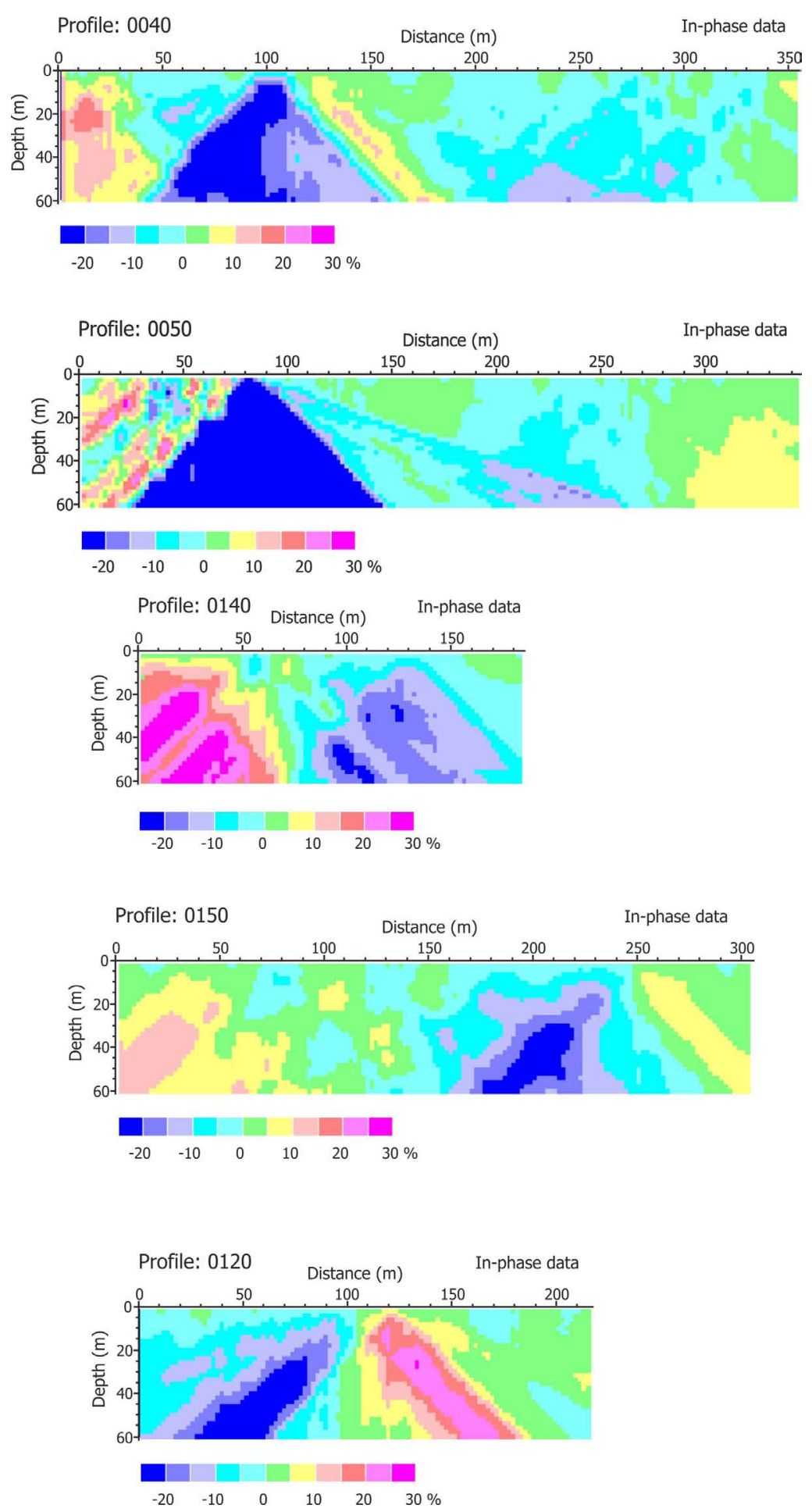

Fig. 4. VLF interpreted filtered data in study area. I

Pис. 4. Интерпретированные отфильтрованные данные низкочастотной электроразведки исследуемой области. 


\section{Resistivity survey}

Resistivity measurements were also conducted in the area of Delfini westwards from spring SP1 (fig. 2). Fourteen (14) soundings (VES) were carried out, using the Schlumberger configuration and further three (3) in situ measurements were conducted. The main purpose of this investigation was to outline the inward extension of seawater front and to characterize the nature of the basement in the NE extension of faults F2 and F3. Although the geoelectrical data were processed by applying the automatic method of Zohdy and Bisdorf [Zohdy, 1989] and the commercial software packages IX1D $\left(\mathrm{v}^{3}\right)$ of Interpex (2006) and WinSev of W-GeoSoft, the final interpretation was based on IX1D package. A 3D representation of the geoelectrical basement has also been produced (fig. 5), a visualization successfully used in the past by the authors [Alexopoulos, Dilalos, 2010]. According to these resistivity results (high resistivity values, $>250 \mathrm{Ohm} . \mathrm{m}$ ), the basement in the area between the soundings D01, D02, D08 is composed of carbonate rocks at depths greater than 20 meters (fig. 5). The area between soundings D03, D09 and D10 presents lower resistivity values $(<60 \mathrm{Ohm} . \mathrm{m})$ up to depths of 40 meters.

The geological formation with such resistivity values is compatible with the presence of clastic rocks of the allochthonous series. At depths greater than 40 meters, highly resistive ( $>300$ Ohm.m) formations of probably carbonate nature are present. The geoelectric sounding D04 showed very low resistivity values $(\sim 6 \mathrm{Ohm} . \mathrm{m})$ indicating the inward (inland) intrusion of seawater. The area south of sounding D04 is swampy, not allowing further investigation of this area. The interesting point here is that sounding D04 lies at an elevation of approximately 6 meters above sea level and the low ( $\sim 6$ Ohm.m) resistivity value was detected at positive elevation of about $1 \mathrm{~m}$ below ground surface. The spring SP1 that is close to sounding D04 shows similar behavior. All resistivity measurements were carried out during July 2007, at times where fresh water discharges were low. Measurements of water conductivity made in the well W1 (fig. 3) showed high content of chloride ions during August 2007. The well is close to geoelectric sounding D14 (about

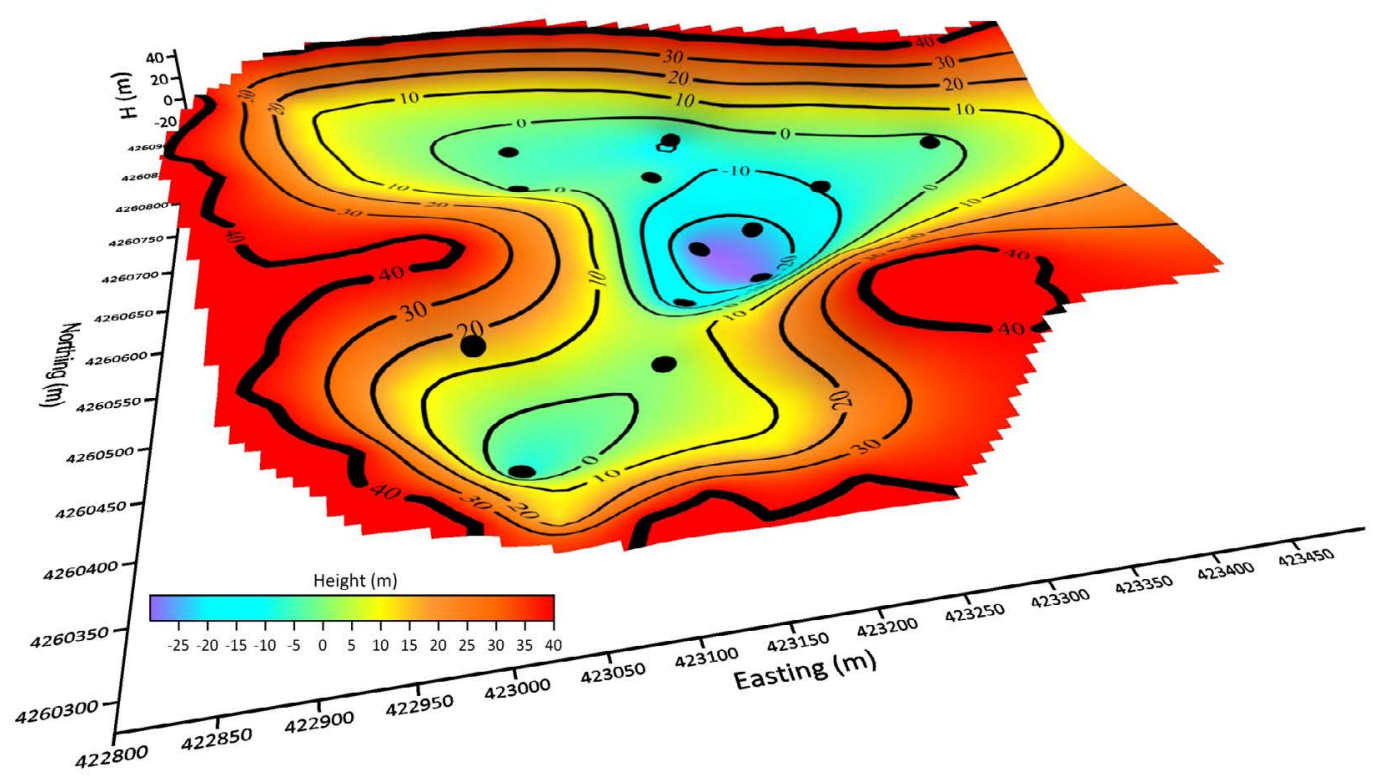

Fig. 5. 3D representation of the geoelectrical basement (limestones/dolomites). /

Рис. 5. Трехмерное изображение геоэлектрического фундамента (известняки/доломиты). 
10 meters) and its water level was at an elevation of about 5-5.5 meters. The chloride content indicates the affect of seawater intrusion inland and according to resistivity values found in this area, the seawater front must be extended close to the area of geoelectrical soundings D09 and D10.

\section{Integrating geophysical and geological results}

In order to integrate geophysical results and geological data obtained from the area of Delfini, two cross sections were drawn in NE-SW (Section 1) and NNE-SSW (Section 2) directions respectively (fig. 2). These two sections are shown in figure 6. The subsurface geological setting of Delfini plain is composed of five mainly formations, two of which are the shallow clastic deposits (Ci-s) and the deeper clastic rocks $(\mathrm{Ci})$ which are both impermeable ones. The presence of the shallow impermeable clastic deposits keep out the sea water intrusion inland and seems that the only free passage of sea water intrusion is through the alluvial and shore deposits NE-ward of sounding D14. The alluvial deposits in this area extend below sea level, allowing thus the seawater intrusion. Below the alluvial and clastic deposits are extended the permeable limestone-dolomite (Ji) and dolomitelimestone ( $\operatorname{Tr} \mathrm{m}$ ) formations that form a confined aquifer. The presence of fault $\mathrm{F} 2$ in cross section 2, which is extended further to NE, might discharge great quantities of fresh water in the plain of Delfini. The presence of fault F1 might also discharge quantities of fresh water but if this fault extends further SE to Delfini gulf, it could work as well as a canal
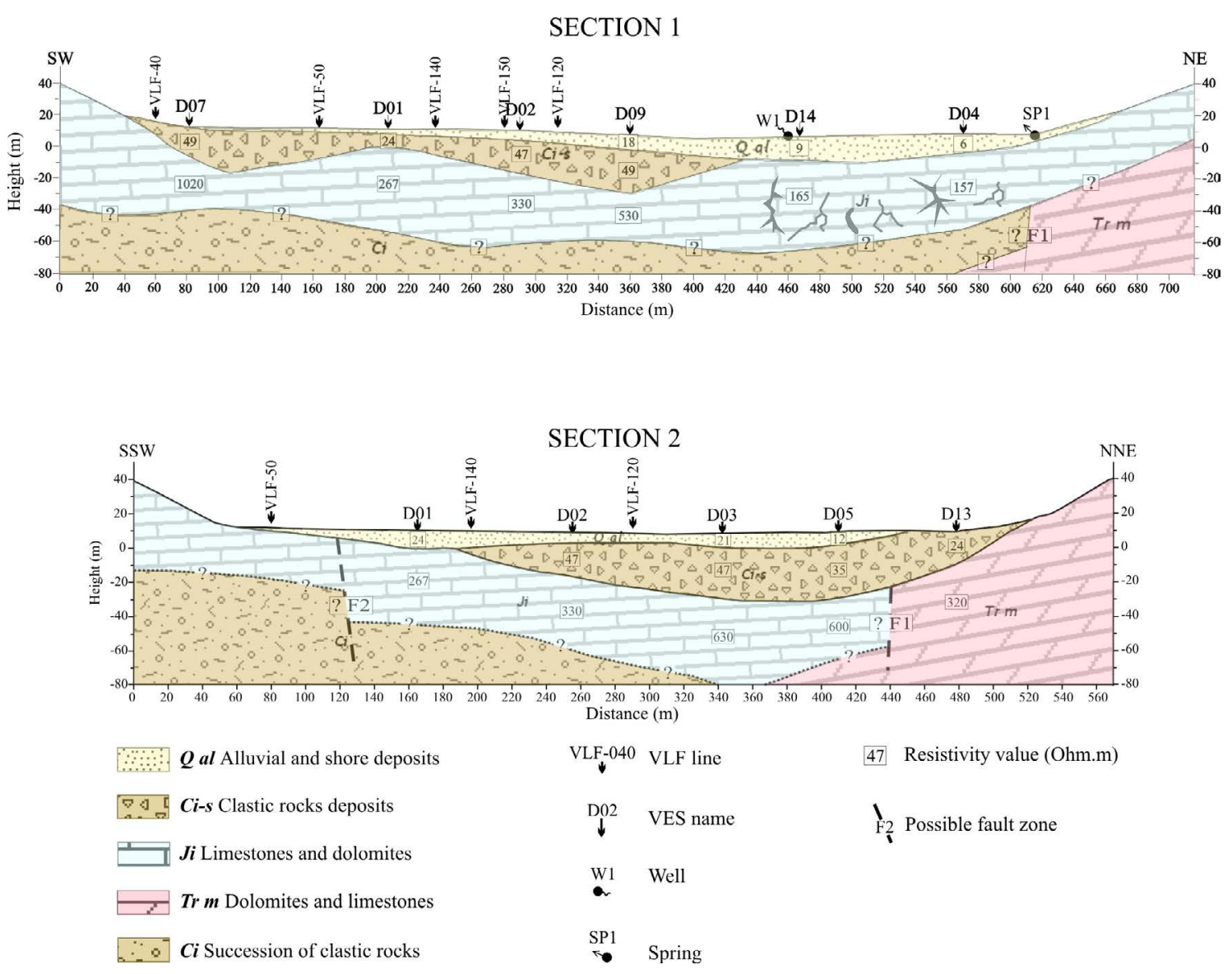

Fig. 6. Integrated geological and geophysical data. /

Рис. 6. Интегрированные геолого-геофизические данные. 
for seawater intrusion inland. It is thought that the presence of the impermeable clastic deposits and clastic rocks create a confined aquifer of fresh water affected by saline water especially during summer time when the fresh water discharge is low. This mechanism can explain the presence of brackish waters at positive elevations during summer time.

\section{Conclusions}

The target of drilling new exploitation wells in the broader area of Delfini at NE side of Chios island was fulfilled, by exploring through geophysical methods the hydrogeological regime and detecting sites of fresh water potential. By combining VLF and geoelectrical results along with geological data it was possible to determine the mechanism and lateral feeding of the springs SP1, SP2 and SP3 which provide huge discharges during winter and spring times. The confined aquifer composed mainly of limestones is overlain by impermeable clastic deposits (Ci-s) which although cover a large part of Delfini plain, allow the fresh water and/or seawater to rise above sea level beyond geoelectrical sounding D14. This is possible since the permeable alluvial deposits lie directly on the limestone basement (fig. 6). The lateral fresh water feeding comes from fault F2 that is extended further to NE in the Delfini plain. Fault F1 might discharge some quantities of fresh water at springs SP1 and SP2 but probably works as a canal for seawater intrusion inland.

\section{References}

1. Albouy Y., Andrieux P., Rakotondrasoa G., Ritz M., Descloitres M., Join J.L., Rasolomanana E. Mapping Coastal Aquifers by Joint Inversion of DC and TEM Soundings - Three Case Histories. Groundwater. 2001. 39 (1). Pp. 87-97. https://doi.org/10.1111/j.1745-6584.2001.tb00354.x

2. Alexopoulos, J. D., Dilalos, S. Geophysical research for geological structure determination in the region of South Mesogheia (Attica). Bulletin of the Geological Society of Greece. 2010. 43 (4). pp. 1898-1906. http://dx.doi.org/10.12681/bgsg.11381

3. Alexopoulos J.D., Dilalos S., Vassilakis E. Adumbration of Amvrakia's spring water pathways, based on detailed geophysical data (Kastraki - Meteora). In: Lambrakis N., Stournaras G., Katsanou K. (eds.), Advances in the Research of Aquatic Environment. Environmental Earth Sciences. Springer, Berlin, Heidelberg. 2011. 2. pp. 105-112. https://doi.org/10.1007/978-3642-24076-8_13

4. Alexopoulos J., Vassilakis Em., Dilalos S. Combined geophysical investigations for detailed groundwater flow modeling in tectonically deformed fractured rocks. Annals of Geophysics. 2013. 56 (6), S0669. 7 p. https://doi.org/10.4401/ag-6236

5. Alexopoulos J.D., Dilalos S., Mitsika G. S., Poulos S. E. Mapping of deltaic aquifers with the combined application of DC and TEM soundings. In: Near Surface Geoscience 2019, 25th European Meeting of Environmental and Engineering Geophysics. 2019. We_25_P13. 5 p. https://doi.org/10.3997/2214-4609.201902468

6. Alexopoulos J.D., Vassilakis Emm., Dilalos S., Papadopoulos T.D. Contribution of geophysical approach for the definition of subsurface flow paths at coastal wetlands. Proceedings of the $8^{\text {th }}$ International Hydrogeological Congress of Greece $\& 3^{\text {rd }}$ MEM Workshop on fissured rocks Hydrology. 2008. 2. pp. 421-430.

7. Alexopoulos J.D., Tomara V., Vassilakis EM., Papadopoulos T.D., Dassenakis M., Poulos S., Voulgaris N., Dilalos S., Ghionis G., Goumas G., Pirlis E. A contribution to environmental Research of The Korissia Coastal Wetland (Corfu Isl., Greece), With the Application of Combined Geological and Geophysical Methods Supported by Geographic Information Systems. Bulletin of Geological Society of Greece. 2007. 40 (4). pp. 1892-1903. http://dx.doi.org/10.12681/bgsg.17187

8. Banks D., Rohr-Torp E., Skarphagen H. Groundwater resources in hard rock. Experiences from the Hvaler study, Southeastern Norway. Hydrogeology Journal. 1994. Vol.2, Issue 2. pp. 33-42. 
9. Banos Ch., Parasxoudis V., Pippidis M. Reformation of the water balance of Chios Island - An integrated water resources management. Proceedings of $3^{\text {rd. }}$ Hydrogeological Congress, Herakleion, Crete. 1995. pp. 428-442.

10. Bernard G., Valla P. Groundwater exploration in fissured media with electrical and VLF methods. Geoexploration. 1991. 27. Pp. 81-91.

11. Besenecker H., Durr S., Herget G., Jacobshagen V., Kauffman G., Ludtke G., Roth W., Tietze K. V. Geologie von Chios (Agais). Geol. Palaeontol. 1968. 2. pp. 121-150.

12. Benson A.K., Payne K.L., Stubben M.A. Mapping groud-water contamination using dc resistivity and geophysical method - a case study. Geophysics. 1977. 62 (1). pp. 80-86. https:// doi.org/10.1190/1.1444148

13. Covel C. L., Kaymen D. T., Phillips I. M., Harrison J. C. VLF Geophysics: A case study in locating bedrock wells in water-bearing fracture zones for use in contaminant migration interception. Proc. SAGEEP 1996 Annual Conf. 1996. pp. 61-79.

14. Dilalos, S. Exploration of hydrogeological and environmental conditions with geophysical techniques, at selected sites in Chios island (Greece) M. Sc Thesis. National and Kapodistrian University of Athens, Faculty of Geology and Geoenvironment. Athens. 2009.

15. Gustafson P., Krasny J., Crystalline rock aquifers: Their occurrence, use and importance. Hydrogeology Journal. 1994. Vol. 2. Issue 2. pp. 64-75.

16. Hayles J.G., Sinha A. K. A portable local loop VLF transmitter for geological fracture mapping. Geophysical Prospecting. 1986. 34. pp. 873-896.

17. Karous M., Hjelt S.E. Linear filtering of VLF dip-angle measurements, Geophysical Prospecting. 1983. 31. pp. 782-794. https://doi.org/10.1111/j.1365-2478.1983.tb01085.x

18. Kauffmann G. Die Geologie von Nordost-Chios (Agais). PhD Thesis, Universitaet Marburg, Germany. 1969.

19. Monteiro Santos F. A, Mateus A., Figueiras J., Concalves M.A. Mapping groundwater contamination around a landfill facility using the VLF-EM method - A case study. Journal of Applied Geophysics. 2006. 60. pp. 115-125. https://doi.org/10.1016/j.jappgeo.2006.01.002

20. Ogilvy R.D., Lee A.C. Interpretation of VLF-EM in-phase data using current density pseudosections. Geophysical Prospecting. 1991. 39. pp. 567-580. https://doi. org/10.1111/j.1365-2478.1991.tb00328.x

21. Papadopoulos T. D., Alexopoulos J. Combined geophysical methods for cavity detection in highly inhomogeneous material over karstic basement. A case history. Proceedings of the $5^{\text {th }}$ Meeting of the Environmental and Engineering Geophysical Society, Budapest, Hungary, VoP6. 1999. https://doi.org/10.3997/2214-4609.201406523

22. Paraskevopoulos P., Papadopoulos T. D. VLF measurements for delineating conductive zones in hard rock environment. $1^{\text {st }}$ Workshop on Hardrock Hydrogeology of the Middle East Mediterranean (MEM), Tinos Island, Greece. 2002. pp. 51-57.

23. Sharma S.P., Baranwal V.C. Delineation of groundwater-bearing fracture zones in a hard rock area integrating very low frequency electromagnetic and resistivity data. Journal of Applied Geophysics. 2005. 57. pp. 155-166. https://doi.org/10.1016/j.jappgeo.2004.10.003

24. Sree Devi P. D., Srinivasulus S., Kesava K. Raju. Delineation of groundwater potential zones and electrical resistivity studies for groundwater exploration. Environmental Geology. 2001. Vol. 40. Issue 10. pp. 1252-1264.

25. Stournaras G., Papadopoulos T. D., Panagopoulos A. Reconnaisances geologiques et geophysiques du site du barrage de Kalamoti (Chios, Grece). Bull. of the Inter, Assoc. of Engin. Geol. 1993. No. 47. pp. 151-158. https://doi.org/10.1007/BF02639604

26. Walen P.A. Ramag 2, VLF survey planning and interpretation software. 2003.

27. Yang C.H., Tong L. T., Huang C.F. Combined application of dc and TEM to sea-water intrsion mapping. Geophysics. 1999. 64 (2). pp. 417-425. https://doi.org/10.1190/1.1444546

28. Zohdy A.A. R. A new method for the automatic interpretation of Schlumberger and Wenner soundings curves. Geophysics. 1989. 54 (2). pp. 245-253. https://doi.org/10.1190/1.1442648 